\title{
PENGARUH KARAKTERISTIK PEKERJAAN DAN STRESS KERJA TERHADAP KINERJA KARYAWAN BIDANG TP-OP DINAS PSDA PROV SUMBAR
}

\author{
Dian Eka Hasdi, Zusmawati \\ Sekolah Tinggi Ilmu Ekonomi KBP \\ Dianekahasdi11@yahoo.com
}

\begin{abstract}
This research aims to know the influence of characteristics of work and stress of work on performance of employees field TP-OP Department PSDA Prov. West Sumatra, this research independent variable i.e. conflict of characteristics of work and stress of work, while the dependent variable i.e. the performance of employees. The population used in this study are employees who work, this research sample as many as 32 people respondents and techniques used is Pusposive Sampling (sample retrieval based on criteria or specific terms). The analysis used in the study include the test validity, reliability test, test, test the classical assumption multikolinieritas, heterokedastisitas test, multiple linear regression analysis, koefisiendeterminasi, hypothesis testing that includes testing of the $t$ test, $F$, and the coefficient of Determination (R2). Partially pointed out that conflicts do not affect significant characteristics on performance of employees. While significant positive effect of work stress on performance of employees. Therefore, to improve the performance of employees, work stress seoptimal may need to be managed by giving an appropriate workload.
\end{abstract}

Keywords: conflict characteristics, work stress and performance

\section{PENDAHULUAN}

Sumber daya manusia merupakan salah satu unsur organisasi dan mempunyai peranan yang penting dalam kegiatan organisasi. Menurut Notoatmodjo (2009) mengemukakan manusia sebagai salah satu komponen organisasi merupakan sumber daya penentu tercapai nya visi dan misi organisasi. Hal yang penting dalam pengelolaan sumber daya manusia adalah karakteristik pekerjaan.

Menurut Stephen Robbins (2006), karakteristik pekerjaan adalah upaya mengidentifikasikan karakteristik tugas dari pekerjaan, bagaimana karakteristik itu digabung untuk membentuk pekerjaan yang berbeda dan hubungannya dengan kepuasan kerja dan kinerja karyawan.

Karakteristik pekerjaan adalah sebuah pendekatan dalam merancang pekerjaan yang menunjukkan bagaimana pekerjaan dideskripsikan kedalam lima dimensi inti yaitu keanekaragaman keterampilan, identitas tugas, arti tugas, otonomi dan umpan balik (Robbins dan Judge, 2007:268).

Pendekatan karakteristik pekerjaan merupakan tindak lanjut dari proses rancangan pekerjaan. Faktor lain yang mempengaruhi kinerja pegawai adalah stress kerja . Stres kerja adalah suatu bentuk tanggapan seseorang, baik fisik maupun mental terhadap suatu perubahan di lingkungannya yang dirasakan mengganggu dan mengakibatkan dirinya terancam (Anoraga 2001:108). 
Stress merupakan sesuatu yang tidak menyenangkan atau dapat mengganggunya. Respon seorang individu terhadap stres tergantung pada kepribadian, sumber-sumber daya yang ada untuk membantu mereka mengatasi, dan konteks dimana stress terjadi (Daft, 2006 : 290) .

\section{Ketertarikan Karakteristik Pekerjaan terhadap Kinerja Karyawan}

Karakteristik pekerjaan merupakan sifat dari tugas yang meliputi tanggung jawab, macam tugas dan tingkat kepuasan yang diperoleh dari pekerjaan itu sendiri (Subyantoro, 2009:12).

Sedangkan karakteristik pekerjaan menurut Handaru, dkk (2013:242) adalah sifat yang berbeda antara jenis pekerjaan yang satu dengan pekerjaan lainya yang bersifat khusus dan merupakan inti pekerjaan yang berisikan sifat-sifat yang ada didalam semua pekerjaan serta dirasakan oleh para pekerja sehingga mempengaruhi perilaku kerja terhadap pekerjaannya.

Selain itu tingkat otonomi yang tinggi akan membangkitkan rasa tanggung jawab yang lebih besar dan apabila disediakan umpan balik yang memadai, karyawan akan mengembangkan suatu pemahaman yang berguna mengenai peranan dan fungsi mereka dengan lebih baik (Djastuti, 2011:4).

Berdasarkan argumentasi diatas, maka dibangun hipotesis pertama, yaitu:

H1: Diduga terdapat pengaruh positif antara Variabel Karakteristik Pekerjaan terhadap kinerja karyawan

\section{Ketertarikan Stress Kerja terhadap Kinerja Karyawan}

Stres yang dialami oleh karyawan merupakan masalah bagi perusahaan yang perlu diperhatikan guna meningkatkan kualitas sumber daya manusia.

Definisi stres kerja menurut Dewi, dkk (2014:4) yaitu, ketegangan yang dialami karyawan karena adanya ketidak seimbangan antara tuntutan pekerjaan dengan kemampuan karyawan dalam menyelesaikan pekerjaanya.

Menurut Handoko (2008:200), stres adalah suatu kondisi ketegangan yang mempengaruhi emosi, proses berpikir dan kondisi seseorang. Tingkat stres yang terlalu tinggi dapat mengancam kemampuan seseorang untuk menghadapi lingkungan. Sebagai hasilnya, pada diri karyawan berkembang berbagai gejala stres yang dapat mengganggu pelaksanaan kerja mereka.

Berdasarkan argumentasi diatas , maka dibangun hipotesis kedua , yaitu :

H2: Diduga terdapat pengaruh positif antara Stress kerja terhadap kinerja karyawan

\section{Ketertarikan Kinerja karyawan terhadap karakteristik dan stress kerja}

Kinerja karyawan adalah hasil kerja secara kualitas dan kuantitas yang dicapai oleh seseorang pegawai dalam melaksanakan tugasnya sesuai dengan tanggung jawab yang diberikan kepadanya (Mangkunegara, 2008:18).

Tingkat keberhasilan suatu kinerja meliputi aspek kuantitatif dan kualitatif. Sedangkan , menurut Siswanto (dalam Muhammad Sandy, 2015:11) kinerja ialah prestasi yang dicapai oleh seseorang dalam melaksanakan tugas dan pekerjaan yang diberikan kepadanya.

Pengertian kinerja menurut Stephen Robbins yang diterjemahkan oleh Harbani Pasolong "Kinerja adalah hasil evaluasi terhadap pekerjaan yang dilakukan oleh karyawan dibandingkan criteria yang telah ditetapkan sebelumnya" (Pasolong, 2007:176). 
Berdasarkan argumentasi diatas, maka dibangun hipotesis ketiga, yaitu:

H3: Diduga terdapat pengaruh positif antara variabel karakteristik pekerjaan terhadap stress kerja

\section{METODE PENELITIAN}

\section{Data dan Sampel}

Jenis penelitian yang digunakan dalam penelitian ini adalah penelitian kuantitatif. Menurut Sugiyono (2014) penelitian kuantitatif digunakan untuk meneliti pada populasi atau sampel tertentu.

Teknik pengambilan sampel pada penelitian ini adalah total sampling. (Sugiyono, 2007) Total sampling adalah teknik pengambilan sampel diamana jumlah populasi sama dengan jumlah sampel. Alasan mengambil teknik total sampling karena jumlah populasi yang kurang dari 100 dan seluruh populasi dijadikan sampel penelitian yang berjumlah 32 personil.

Jenis data dalam penelitian ini adalah data primer dan sekunder seperti, menyebarkan kuesioner berupa pertanyaan tertulis, dan dokumentasi seperti melihat atau mencatat dokumen - dokumen perusahaan yang berkaitan dengan penelitian.

\section{HASIL PENELITIAN}

\section{Uji Asumsi Klasik}

\section{Uji Normalitas}

Uji normalitas adalah pengujian tentang kenormalan distribusi data. Penggunaan uji normalitas karena pada analisis statistik parametik, asumsi yang harus dimiliki oleh data adalah bahwa data tersebut harus terdistribusi secara normal. Maksud data terdistribusi secara normal adalah bahwa data akan mengikuti bentuk distribusi normal

Hasil Uji Normalitas

\section{One-Sample Kolmogorov-Smirnov Test}

\begin{tabular}{lrr}
\hline N & & 32 \\
Normal Parameters & Mean & 0000000 \\
& Std. Deviation & 1.48905214 \\
Most Extreme & Absolute & .127 \\
Differences & Positive & .127 \\
& Negative & .065 \\
Kolmogorov-Smirnov Z & .716 \\
Asymp. Sig. (2-tailed) & .684 \\
& \\
a. Test distribution is Normal. & \\
\hline \multicolumn{2}{c}{ Data diolah, 2018 } \\
\multicolumn{2}{c}{ Berdasarkan hasil uji normalitas diketahui nilai signifikansi 0,684 lebih } \\
besar dari batas signifikannya yaitu 0,05. Maka dapat disimpulkan bahwa nilai \\
residual berdistribusi normal.
\end{tabular}




\section{Uji Multikolinearitas}

Uji ini bertujuan untuk menguji apakah model regresi ditemukan adanya korelasi antar variabel bebas (independen).Model regresi yang baik seharusnya tidak terjadi korelasi di antara variabel bebas.Jika variabel bebas saling berkorelasi, maka variabel-variabel ini tidak ortogonal.

Hasil Uji Multikolinearitas

Coefficients $^{a}$

Model

Collinearity Statistics

\begin{tabular}{lll}
\multicolumn{2}{c}{ Tolerance } & VIF \\
\hline 1 (Constant) & & \\
X1 & .766 & 1.306 \\
X2 & .766 & 1.306 \\
\hline
\end{tabular}

Data diolah, 2018

Dari hasil yang didapatkan bahwa semua nilai VIF $<10$ ini berarti tidak terjadi multikolonieritas. Maka kesimpulannya bahwauji multikolinearitas terpenuhi.

\section{Uji Heteroskedastisitas}

Uji Heteroskedastisitas dengan Uji Glejser bertujuan untuk mengetahui apakah sebuah model regresi terjadi ketidaksamaan variance dari residual satu pengamatan ke pengamatan yang lain.

\section{Hasil Heteroskedastisitas}

Coefficients $^{a}$

\begin{tabular}{llrl} 
Model & $\mathrm{T}$ & Sig. \\
\hline 1 & (Constant) & 2.781 & \\
X1 & -1.324 & .009 \\
X2 & 4.495 & .196 \\
\hline
\end{tabular}

a. Dependent Variable: $Y$

Sumber : data diolah, 2018

Dari hasil Uji Glejser X1 dengan nilai signifikasn 0,196 di artikan tidak terjadi masalah pada data dikarenakan lebih besar dari 0,05 sedangkan X2 terjadi masalah pada data dikarenakan nilai signifikan 0,000 lebih kecil dari 0,05.

\section{Analisis Regresi Berganda}

Hasil Uji Analisis Regresi Berganda

\begin{tabular}{|c|c|c|c|c|c|}
\hline \multicolumn{6}{|c|}{ Coefficients $^{a}$} \\
\hline \multirow{2}{*}{ Model } & $\begin{array}{r}\text { Unstanc } \\
\text { Coeffi }\end{array}$ & $\begin{array}{l}\text { ardized } \\
\text { ients }\end{array}$ & $\begin{array}{c}\text { Standardize } \\
\mathrm{d} \\
\text { Coefficients }\end{array}$ & & \\
\hline & $B$ & Std. Error & Beta & $\mathrm{T}$ & Sig. \\
\hline 1 (Constant) & 17.044 & 6.128 & & 2.781 & .009 \\
\hline$X 1$ & -.160 & .121 & -.214 & -1.324 & .196 \\
\hline$x 2$ & .728 & .162 & .725 & 4.495 & .000 \\
\hline
\end{tabular}

a. Dependent Variable: $Y$ 
Dari gambar diatas dapat dilihat bahwa pola membentuk garis lurus atau diagonal diatas dan dibawah angka 0 pada sumbu y, maka dapat disimpulkan terjadi heteroskedastisitas salah satu diantara dua variable bebas. persamaan regresi linear berganda untuk pengaruh karakteristik pekerjaan dan stress kerja terhadap kinerja karyawan pada bidang TP-OP dinas PSDA adalah sebagai berikut :

$\mathbf{Y}=\mathbf{a}+\mathbf{b}_{1} \mathbf{X}_{1}+\mathbf{b}_{2} \mathbf{X}_{2}+\mathbf{e}$

$\mathrm{Y}=31.337+0221 \mathrm{X}_{1}+0,243 \mathrm{X}_{2}+\mathrm{e}$

Maka dapat disimpulkan bahwa variabel bebas $\mathrm{X}_{1}$ (Karakteristik) dengan kofisien $-0,160$ tidak berpengaruh. Kemudian variabel lain berpengaruh adalah $X_{2}$ (Stres Kerja) dengan koefisien 0,728 dari persamaan tersebut dilihat bahwa variabel karakteristik tidak berpengaruh positif terhadap kinerja. Sedangkan variabel Stress Kerja berpengaruh positif terhadap kinerja dimana persamaan regresi dua predictor $\beta$ Inegativ dan $\beta 2$ bertanda positif, maka dapat diartikan bahwa satu satuan skor kinerja akan dipengaruhi oleh karakteristik sebesar -0,160 dan stress kerja sebesar 0,728 pada konstanta 17.044.

Hasil Uji Determinasi

\section{Hasil Uji Koefisien Determinasi Model Summary}

Model R R Square Adjusted R Square Std. Error of the Estimate

$\begin{array}{lllll}1 & .649^{\mathrm{a}} & .422 & .382 & 1.53954\end{array}$

a. Predictors: (Constant), X2, X1

Sumber: data diolah 2018

Berdasarkan hasil pengolahan data, maka dihasilkan nilai Adjusted R Square yang mempunyai nilai 0,382 yang berarti pengaruh variabel $\mathrm{X}$ terhadap $\mathrm{Y}$ adalah $0,3 \%$. Artinya dijelaskan oleh variabel lain seperti motivasi dan lingkungan kerja.

\section{Hasil Uji Parsial (T)}

\begin{tabular}{|c|c|c|c|c|c|c|}
\hline \multicolumn{7}{|c|}{ Hasil Uji Parsial (T) } \\
\hline \multirow{3}{*}{\multicolumn{2}{|c|}{ Model }} & \multicolumn{3}{|c|}{ Coefficients $^{\mathrm{a}}$} & & \\
\hline & & \multicolumn{2}{|c|}{$\begin{array}{l}\text { Unstandardized } \\
\text { Coefficients }\end{array}$} & \multirow{2}{*}{$\begin{array}{c}\text { Standardize } \\
d \\
\text { Coefficients } \\
\text { Beta }\end{array}$} & \multirow[b]{2}{*}{$\mathrm{T}$} & \multirow[b]{2}{*}{ Sig. } \\
\hline & & B & Std. Error & & & \\
\hline & (Constant) & 17.044 & 6.128 & & 2.781 & .009 \\
\hline & $\mathrm{X} 1$ & -.160 & .121 & -.214 & -1.324 & .196 \\
\hline & $\mathrm{x} 2$ & .728 & .162 & .725 & 4.495 & .000 \\
\hline & Jependent & le: Y & & & & \\
\hline
\end{tabular}

Sumber: data diolah 2018

Berdasarkan tabel maka pengaruh karakteristik dan stress kerja terhadap kinerja karyawan adalah sebagai berikut :

Berdasarkan hasil pengolahan data dapat dilihat bahwa nilai signifikasi t-hitung $(1,324)$ dan nilai signifikansinya $0,196 \mathrm{Hal}$ ini berarti signifikasi lebih besar dari 0,05 . Hal ini menunjukkan ada pengaruh yang positif dan tidak signifikan antara karakteristik 
terhadap kinerja karyawan. Jadi hipotesisnya Ho diterima Ha ditolak, artinya tidak ada pengaruh yang signifikan antara karakteristik terhadap kinerja karyawan.

Berdasarkan hasil pengolahan data dapat dilihat bahwa nilai signifikasi t-hitung (4.495) dan nilai signifikansinya 0,000. Hal ini berarti signifikasi lebih kecil dari 0,05. Hal ini menunjukkan ada pengaruh yang signifikan antara stres kerja terhadap kinerja karyawan. Jadi hipotesisnya Ho ditolak Ha diterima, artinya ada pengaruh yang signifikan antara stress kerja terhadap kinerja karyawan TP-OP pada Dinas PSDA Provinsi Sumatera Barat.

Hasil Uji Simultan (F)

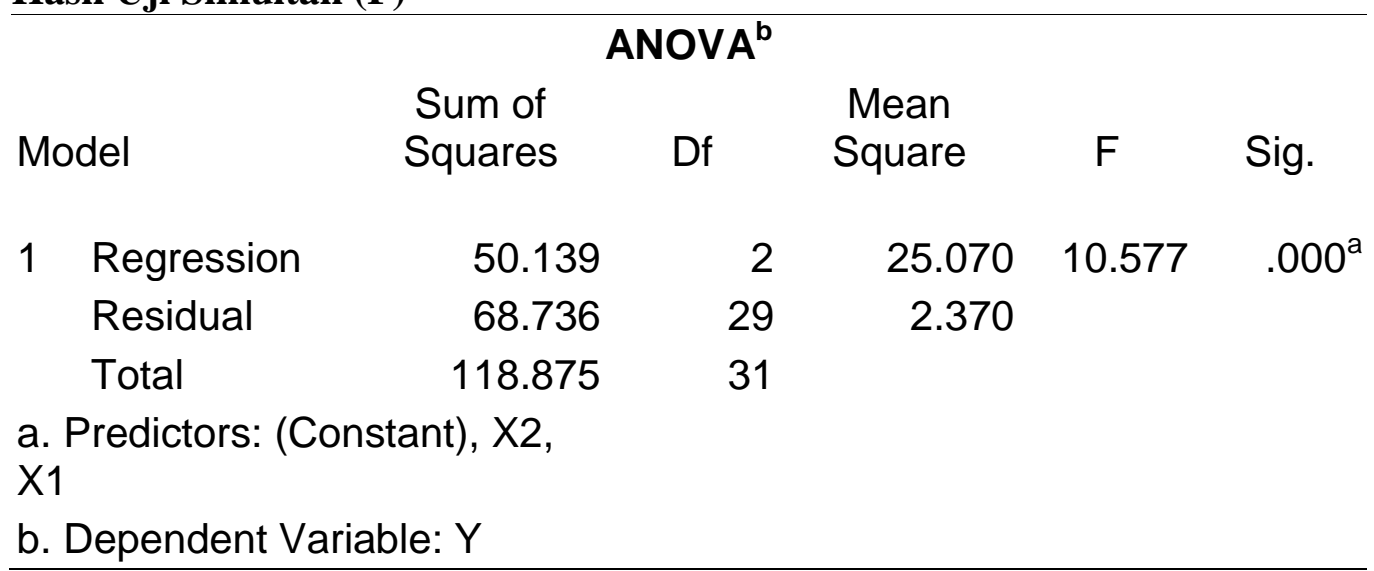

Sumber: data diolah 2018

Berdasarkan hasil pengolahan data dapat dilihat bahwa nilai signifikasi $\mathrm{F}$ hasil pengujian sebesar 0,000 seperti yang dikemukakan pada tabel 4.17. Hal ini berarti signifikasi $\mathrm{F}$ lebih kecil dari 0,05 . Hal ini menunjukkanada pengaruh yang positif dan signifikan secara simultan/serempak antara karakteristik dan stress kerja terhadap kinerja karyawan. Jadi hipotesisnya Ho ditolak Ha diterima.

\section{PEMBAHASAN}

\section{Pengaruh Karakteristik Terhadap Kinerja Karyawan}

Berdasarkan hasil penelitian yang diperoleh setelah dilakukan pengujian terhadap 32 orang responden yang merupakan karyawan TP-OP Dinas PSDA Prov Sumbar maka nilai koefisien regresi karakteristik terhadap kinerja karyawan -0,160 yang berarti apabila karakteristik bertambah maka kinerja karyawan akan berkurang dan dilihat juga hasil nilai thitung variabel karakteristik berpengaruh positif dan signifikan terhadap kinerja karyawan TPOP Dinas PSDA Prov Sumbar karena memiliki nilai thitung untuk variabel karakteristik sebesar -1.324 dengan nilai signifikansi $0.196 \mathrm{Hal}$ ini berarti signifikasi lebih besar dari 0,05. Secara parsial karakteristik individu dan budaya organisasi berpengaruh signifikan terhadap kinerja pegawai Universitas Asahan Kisaran. Variabel yang dominan memiliki pengaruh terhadap kinerja pegawai adalah budaya organisasi.

\section{Pengaruh Stres Kerja Terhadap Kinerja Karyawan}

Berdasarkan hasil penelitian yang diperoleh setelah dilakukan pengujian terhadap 32 orang responden yang merupakan karyawan TP-OP Dinas PSDA Prov Sumbar maka nilai koefisien regresi stress kerja terhadap kinerja karyawan $-0,728$ yang berarti apabila stress kerja bertambah maka kinerja karyawan akan berkurang dan dilihat juga hasil nilai thitung variabel stress kerja tidak berpengaruh positif dan signifikan terhadap kinerja karyawan TPOP Dinas PSDA PRov Sumbar karena memiliki nilai thitung untuk variabel karakteristik sebesar 4.495 dengan nilai signifikansi 0.196 Hal ini berarti signifikasi lebih besar dari 0,00. Sebagai 
hasilnya, pada diri karyawan berkembang berbagai gejala stres yang dapat mengganggu pelaksanaan kerja mereka. Secara parsial variabel stress kerja berpengaruh negative dan signifikan terhadap variabel kinerja karyawan, serta dalam uji $\mathrm{F}$ menyimpulkan bahwa variabel lingkungan kerja dan stress kerja mempunyai pengaruh terhadap kinerja karyawan.

\section{KESIMPULAN}

Berdasarkan uraian dan hasil analisis pada bab sebelumnya mengenai mengetahui Pengaruh Karakteristik dan Stress kerja terhadap Kinerja Karyawan pada Bidang TP-OP Dinas PSDA Prov Sumbar dapat diambil kesimpulan sebagai berikut :

Hasil uji analisis regresi berganda nilai koefisien regresi karakteristik terhadap kinerja karyawan -0,160 yang berarti apabila karakteristik pekerjaan bertambah maka kinerja karyawan akan berkurang dan dilihat juga hasil nilai thitung variabel karakteristik tidak berpengaruh positif terhadap kinerja karyawan TP-OP Dinas PSDA Prov Sumbar karena memiliki nilai thitung untuk variabel karakteristik pekerjaan sebesar -1.324 dengan nilai signifikan 0,196 . Artinya tidak ada hubungan antara karakteristik pekerjaan terhadap kinerja karyawan.

Hasil uji analisis regresi berganda nilai koefisien regresi stress kerja terhadap kinerja karyawan 0,728 yang berarti apabila stress kerja bertambah maka kinerja karyawan akan berkurang dan dilihat juga hasil nilai thitung variabel stress kerja berpengaruh positif terhadap kinerja karyawan TP-OP Dinas PSDA Prov Sumbar karena memiliki nilai thitung untuk variabel stress kerja sebesar 4,495 dengan nilai signifikan 0,000 . Artinya ada hubungan antara stress kerja terhadap kinerja karyawan.

\section{UCAPAN TERIMAKASIH}

Penulisan mengucapkan terima kasih kepada bidang TP-OP Dinas Pengelolaan Sumber Daya Air Provinsi Sumatera Barat yang telah memberikan dana, sehingga penulis dapat melakukan penelitian ini dengan lancar. Ucapan terima kasih juga penulis haturkan kepada Sekolah Tinggi Ilmu "KBP" yang telah memberikan dukungan, izin dan tugas kepada penulis untuk melakukan penelitian dan penulisan jurnal ini.

\section{DAFTAR PUSTAKA}

Agung Nugroho. (2005). Strategi Jitu memilih Metode statistic Penelitian dengan SPSS, Andi Jogyakartaaa

Andini, Yossi Tri. 2005. Faktor-faktor Penyebab Stres Kerja pada pegawai Negeri Sipil Dinas Pasar Kota Semarang. Skripsi S 1 . Fakultas Psikologi UNIKA Soegijapranata. Semarang. Tidak Dipublikasikan

Astuti, Retro Fajar. 2005. Pengaruh Kepercayaan pada Atasan, Kepuasan Kerja, dan Komitmen Organisasi terhadap Kinerja Karyaawan (Studi Emnpiris pada Pegawai PEMKAB Kendal). Tesis S 2. Program Pasca Sarjana Ilmu Manajemen Universitas Diponegoro. Tidak Dipublikasikan.

Aldi, Y., \& Susanti, F. (2019). Pengaruh Stress Kerja Dan Motivasi Kerja Terhadap Prestasi Kerja Karyawan Pada PT. Frisian Flag Indonesia Wilayah Padang. https://doi.org/10.31227/osf.io/et4rn

Andi Setiawan Chan. (2012). Pengaruh Penilaian Kinerja Terhadap Kinerja Karyawan Dengan Motivasi Sebagai Variabel Moderasi. 
Crossman, A. and B. Abou-Zaki, 2003, "Job Satisfaction and Employee Perfomance of Lebanese Banking Staff", Journal of Managerial Psychology, Vol.18,No.4,pg.368376

Dewi., Chadek Novi Charisma, I Wayan Bagia dan Gede Putu Agus Jana Susila. 2014. Pengaruh Stress Kerja dan Kepuasan Kerja terhadap Kinerja Karyawan pada Bagian Tenaga Penjualan UD. Surya Raditya Negara. Bisma Universitas Pendidikan Ganesha Jurusan Manajemen. Vol.2, No.1. donwload.portalgaruda.org/artcle.php?article $=304543 \& v a l=1350$. Diakses Oktober 2015. Hal 1-9

Dessler. Gary.2011. Manajemen Sumber Daya Manusia. Jilid II. PT Prenhallindo. Jakarta Dkk. Ardana. (2008). Perilaku Keorganisasian. Edisi Kedua. Graha Ilmu. Yogyakarta.

Dona, E. (2018). Analisis Motivasi Kerja Ditinjau Dari Lingkungan Kerja Kasus Karyawan LBPP Lia Payakumbuh. Jurnal KBP.

Dona, E. (2016). Pengaruh Perencanaan, Prosedur Dan Pengawasan dan Komitmen Organisasi Dalam Pelaksanaan Anggaran Terhadap Kinerja Pegawai Dinas Pekerjaan Umum Kota Pariaman. Jurnal Riset Manajemen dan Akuntansi (Jurmak), 23-35.

Ferijani,A dan Ika Rahutami. 2001. "Stress Kerja karyawan BPR (Studi Kasus Perbarindo Komda Semarang)". Jurnal Dian Ekonomi. Vol.VII. No.1

Ghezanda, R. (2013). Pengaruh Karakteristik Individu dan Karakteristik Situasi Kerja Terhadap Motivasi Kerja Karyawan. Jurnal Aplikasi Manajemen. Vol 5 (1): 126131.

Ghozali. (2011). Aplikasi Analisis Multivariate dengan Program IBM SPSS 19. Edisi Kelima. Universitas Diponegoro: Semarang.

Ghozali, I. (2009). Aplikasi Analisis multivariat dengan program SPSS.Semarang: BPUniversitas diponegoro.

Grifin, R. W. (2006). Manajemen. Jakarta: Erlangga.

Hadiyanto, Didik. 2013. Pengaruh Kompetensi, Kompensasi, Dan Kepuasan Kerja Terhadap Kinerja Karayawan Pada PT. Ciomas Adisatwa Balikpapan. Jurnal Ekonomi Universitas Balikpapan. Vol.1, No.1. www.journal.unipdu.ac.id\%2Findex.php\%2Fseminas\%2Farticle\%

Hani., H. (2000). Manajemen. Edisi 2. Yogyakarta : BPFE.

Hasibuan, M. (2008a). Manajemen Sumber Daya Manusia. Jakarta: PT. Bumi Aksara.

Husein, N. M. dan A. H. (2012). "Pengaruh Lingkungan Kerja dan Karakteristik Individu Terhadap Kepuasan Kerja Karyawan Hotel Melati Di Kecamatan Banjarmasin Tengah". Jurnal Manajemen dan Akuntansi. Vol. 13. No. 1. April 2012. Hal. 35 44. Sekolah Tinggi Ilmu Ekonomi. Banjarmasin.

Ismiati, N., \& Zusmawati, Z. (2020, March 19). Pengaruh Konflik Peran Ganda Dan Stres Kerja Terhadap Kinerja Polisi Wanita Di Polresta Padang. https://doi.org/10.31219/osf.io/yfjrb

Junaidi, R., \& Susanti, F. (2019). Pengaruh Gaya Kepemimpinan Dan Budaya Organisasi Terhadap Kinerja Pegawai Pada UPTD Baltekkomdik Dinas Pendidikan Provinsi Sumatera Barat. https://doi.org/10.31227/osf.io/bzq75

Mangkunegara,Anwar Prabu. 2006. Manajemen Sumber Daya Manusia Perusaahaan. Cetakan Ketiga, Rosdakarya, Bandung. Indonesia,.

Mangkunegara,Anwar Prabu. 2000. Manajemen Sumber Daya Manusia Perusaahaan. Penerbit: Bumi Aksara, Jakarta.

Mangkunegara,Anwar Prabu. 2009. Manajemen Sumber Daya Manusia Perusaahaan.Bandung:PT.Remaja Rosdakarya.

Mayliza, R. (2019). Pengaruh Konflik Dan Kejenuhan Terhadap Kepuasan Kerja Karyawan PT. PLN (Persero) Sektor Pembangkitan Dan Pengendalian 
Pembangkitan Ombilin. https://doi.org/10.17605/OSF.IO/DQZ3K

Mayliza, R. (2019). Kontribusi Sistem Penghargaan Dan Lingkungan Kerja Terhadap Efektifitas Kerja Pegawai Pada Kantor Dinas Pendidikan Kota Padang. https://doi.org/10.17605/OSF.IO/VWZH3

Mayliza, R. (2019). Pengaruh Gaya Kepemimpinan Dan Disiplin Kerja Terhadap Kinerja Pegawai, Dengan Motivasi Kerja Sebagai Variabel Intervening (Studi Pada Dinas Pendidikan Kabupaten Tanah Datar). https://doi.org/10.17605/OSF.IO/JGPDN

Nardo, R. Evanita, Syahrizal, S. (2018). Pengaruh Kepemimpinan Transformasional, Dan Lingkungan Kerja Non Fisik Terhadap Perilaku Inovatif. JEBI (Jurnal Ekonomi dan Bisnis Islam) 3 (2), 209-215

Nardo, R. Evanita, Syahrizal, S. (2019). The Effect of Transformational Leadership and Non Physical Work Environment on Innovative Behavior with Work Motivation as a Mediation For Employees of Tour And Travel Companies In West Sumatera. 2nd Padang International Conference on Education, Economics, Business and Accounting (PICEEBA-2 2018)

Nur, Saina. 2013. Konflik, stres Kerja dan Kepuasan Kerja Pengaruhnya terhadap Kinerja Pegawai pada Universitas Khairun Ternate. Jurnal EMBA Fakultas Ekonomi dan Bisnis Universitas Sam Ratulangi. Vol.1, No.1. http://ojs.unud.ac.id/index.php

Luthans, F. (2011). Organizational Behavior, An Evidence Based Approach, Twelfth Edition, McGraw Hill.

Mathis, Robert L, dan J. H. J. (2006). Human Resource Management (Manajemen Sumber Daya Manusia). Edisi 10. Jakarta: Salemba Empat.

Panggabean., M. S. (2002). Manajemen Sumber Daya Manusia. Bogor: Ghalia Indonesia.

Putra, RY. Marlius, D. (2019). Pengaruh Pendidikan, Pengalaman Kerja dan Etos Kerja Terhadap Kinerja Pegawai Di KPN Batur. Academic Conference For Management 2.

Rahmizal, M. (2018). Pengaruh Pendapatan, Pendidikan, Kesehatan, Modal Sosial Dan Religiusitas Terhadap Kebahagiaan Individu Di Indonesia. Universitas Gadjah Mada

Rivai. (2008a). Manajemen Sumber Daya Manusia untuk Perusahaan .PT.Raja Grafindo Persada: Jakarta.

Rivai, V. dan E. J. S. (2008b). Manajemen Sumber Daya Manusia. Jakarta.

Robbins, S. P. (2001). Manajemen Konflik (Upaya Penyelesaian Konflik Dalam Organisasi). https://doi.org/10.1007/s13398-014-0173-7.2

Susriyanti, S. Nardo, R. (2019). Pengaruh Fungsi Komunikasi Dan Kepuasan Kerja Karyawan Terhadap Pemberian Pelayanan Nasabah PT. BPR LPN Talawi Sakato. Jurnal Administrasi Sosial dan Humaniora 3 (2), 97-111.

Sekaran, U. (2006). Metodelogi Penelitian Untuk Bisnis. Jakarta: Salemba Empat.

Siagian, S. P. (2003). Pengaruh Gaya Kepemimpinan Demokratis Terhadap Kinerja Pegawai Pada Kantor Sekretariat Daerah Kota Samarinda Mardiana ${ }^{1}$.

Sugiyono. (2005). Metode penelitian pendidikan: pendekatan kuantitatif, kualitatif, dan R\&G. Bandung. Alfabeta.

Sugiyono. (2007). Metode Penelitian Kuantitatif Kualitatif dan R\&D. Bandung: Alfabeta. Sugiyono. (2014). Metode Penelitian Manajemen. Pendekatan: Kuantitatif, Kualitatif, Kombinasi, Penelitian Tindakan, Penelitian, Penelitian Evaluasi. Bandung. Alfabeta.

Thoha, M. (2007). Perilaku Organisasi: Konsep Dasar dan Aplikasi. Penerbit Rajawali, Jakarta.

Widodo, B. H., \& Susanti, F. (2019). Pengaruh Human Relation (Hubungan Antar 
Manusia), Lingkungan kerja Terhadap Etos Kerja karyawan (Studi Kasus Pada PT. Pelindo Teluk Bayur Padang ). https://doi.org/10.31227/osf.io/dxm8a 